\title{
Epidemiological analysis of strains of Salmonella enterica serotype Enteritidis from foodborne outbreaks occurring in Italy, 1980-1994
}

\author{
A. NASTASI, C. MAMMINA, M. FANTASIA* and M. PONTELLO $\dagger$
}

Centro per gli Enterobatteri Patogeni dell'Italia Meridionale, Dipartimento di Igiene e Microbiologia ' $G$. $D$ ' Alessandro; Via del Vespro 133, 90127 Palermo, *Centro Nazionale per gli Enterobatteri Patogeni, Istituto Superiore di Sanità, Viale Regina Elena 299, 00161 Roma and + Centro per gli Enterobatteri Patogeni dell'/talia Settentrionale, Istituto di Igiene dell'Università, Via C. Pascal 36, 20133 Milano, Italy

\begin{abstract}
Polymerase chain reaction (PCR-) ribotyping was performed on 243 strains of Salmonella enterica serotype Enteritidis isolated during the years 1980-1994 from 58 foodborne outbreaks occurring in different regions of Italy. The majority (37) of the outbreaks were attributed to phage type (PT) 4, followed by PT1 (seven outbreaks); the latter was identified in 1993 in Italy in epidemic strains of Enteritidis. In eight cases more than one phage type was recognised from a single event. Nine PCR-ribotypes (PCR-RTs) were detected, with a strong prevalence of PCR-RTs f7 and e5 (23 and 21 outbreaks, respectively). In two instances two distinct PCR-RTs were identified within strains from a single outbreak. All but one of the PT1 outbreaks were caused by PCRRT f7, whereas PT4 outbreaks could be subdivided into six subsets. Clustering of isolates was consistent with data obtained from epidemiological investigations. PCRribotyping proved to be an effective and reliable tool for subtyping isolates of Enteritidis belonging to the most frequent phage types. Nevertheless, in terms of laboratory expertise and lack of inter-laboratory standardisation, this typing technique is best suited for reference laboratories.
\end{abstract}

\section{Introduction}

In the past 10 years the incidence of foodborne cases of infection caused by Salmonella enterica serotype Enteritidis has increased dramatically in many countries. Most cases of food-poisoning are related to the ingestion of raw or undercooked eggs or contaminated egg-containing foods $[1,2]$.

Phage typing has become the reference method for the primary subdivision of strains of this serotype for epidemiological investigations. In Europe, the predominant phage type (PT) is PT4, whereas in the USA and Canada the most frequently identified isolates are PT8 [3-5]. In Italy c. $80 \%$ of isolates belong to PT4 [6]. On this basis, phage typing alone appears to be inadequate for monitoring the spread of Enteritidis. Furthermore, changes in phage type occur by acquisition of a plasmid [7], loss of lipopolysaccharide [8] or phage conversion [9]. Likewise, interconversion of

Received 18 June 1996; revised version accepted 22 Sept. 1996.

Corresponding author: Dr A. Nastasi.
PT4 and PT8 has been observed [9], even though epidemiological data confirm their stability under field conditions.

The application of polymerase chain reaction (PCR) ribotyping in molecular subtyping of epidemic and apparently sporadic strains of Enteritidis from Southern Italy has been reported previously [10]. This method uses PCR to amplify the $16 \mathrm{~S}-23 \mathrm{~S}$ intergenic spacer region of the bacterial rRNA operon. Fragment length polymorphisms identified by this technique have been used as an alternative genotyping approach to traditional ribotyping in the analysis of isolates of diverse bacterial species [11-13]. Within isolates of Enteritidis, the application of PCR ribotyping was able to identify multiple clones in the most frequent phage types [10].

In this study, 243 epidemic strains of Enteritidis isolated from 58 foodborne outbreaks occurring in Italy during 1980-1994 were submitted to phage typing and PCR ribotyping. The aim of the present work was to evaluate the effectiveness of this molecular typing method for strains isolated from food-poisoning events previously elucidated by epi- 
demiological investigations carried out by Public Health Services.

\section{Materials and methods}

\section{Bacterial strains}

Two hundred and forty-three strains of Enteritidis from 58 food-poisoning outbreaks that occurred during the years 1980-1994 in Italy were examined. All available isolates from each outbreak were included in the study. In five and 24 cases, respectively, only isolates from food or from clinical cases were available for analysis. In 12 cases only one isolate was obtained.

Enteritidis strains from Southern Italy were referred to the Centre for Enterobacterial Pathogens of Southern Italy (CEPIM) by public health and hospital laboratories. Strains from Northern and Central Italy were provided by the Centre for Enterobacterial Pathogens of Northern Italy (CEPIS) and by the National Centre for Enterobacterial Pathogens (CNEP), Istituto Superiore di Sanità, Rome. Epidemic strains from Southern Italy had been analysed previously by phage typing and PCR ribotyping for comparison with a sample of non-outbreak strains isolated in the same period [10].

All isolates were identified and serotyped by standard techniques [14].

\section{Phage typing}

The strains were phage typed by the method of Ward et al. [15] without significant modifications. Isolates showing lysis patterns consistent with the recognised phage types were designated accordingly, whilst isolates with patterns not conforming to any of the currently identified types were classified as RDNC.

\section{$P C R$ ribotyping}

Whole-cell DNA from each isolate was prepared by the technique described by Kostman et al. [12]. Briefly, pelleted bacterial cells from 1-ml overnight LB broth cultures were resuspended in $50 \mu \mathrm{l}$ of $10 \mathrm{mM}$ Tris- $\mathrm{HCl}$ (pH 8.0)-1 mM EDTA and boiled for $5 \mathrm{~min}$. Cells were then lysed with lysozyme $100 \mu \mathrm{g} / \mathrm{ml}$ at $4^{\circ} \mathrm{C}$ for $15 \mathrm{~min}$ and proteinase $\mathrm{K} 100 \mu \mathrm{g} / \mathrm{ml}$ at $55^{\circ} \mathrm{C}$ for $15 \mathrm{~min}$. After heating at $95^{\circ} \mathrm{C}$ for $15 \mathrm{~min}$, lysates were treated with RNAase $10 \mu \mathrm{g} / \mathrm{ml}$ for $15 \mathrm{~min}$ at $37^{\circ} \mathrm{C}$.

PCR genomic fingerprints were generated by the technique described by Kostman et al. [13] with minor modifications. Amplification reactions were accomplished in $25 \mu \mathrm{l}$ volumes containing $50 \mathrm{~mm}$ $\mathrm{KCl}, 10 \mathrm{mM}$ Tris- $\mathrm{HCl}$ (pH 8.0), Triton X-100 0.1\% $\mathrm{v} / \mathrm{v}, \quad 1.5 \mathrm{mM} \mathrm{MgCl}_{2}, 100 \mu \mathrm{M}$ each deoxynucleoside triphosphate, $25 \mathrm{pmol}$ of each primer and $1.0 \mathrm{U}$ of Taq polymerase (Promega, USA). Primers complementary to conserved regions of rRNA genes were 5'-
TTGTACACACCGCCC-GTCA-3' and 5'-GGTACCTTAGATGTTTCAGTTC-3', respectively [13]. One $\mu 1$ of each bacterial lysate was included as template. A negative control with $1 \mu \mathrm{l}$ of distilled water instead of the DNA sample was used in PCR amplification of each set of samples tested. The temperature cycles were as follows: $95^{\circ} \mathrm{C}$ for $5 \mathrm{~min} ; 95^{\circ} \mathrm{C}$ for $1 \mathrm{~min}, 55^{\circ} \mathrm{C}$ for $1 \mathrm{~min}$ and $72^{\circ} \mathrm{C}$ for $1 \mathrm{~min}$ for 30 cycles; $72^{\circ} \mathrm{C}$ for 5 min [13].

The amplified DNA products were resolved by electrophoresis through acrylamide-bis-acrylamide (59:1) $10 \% \mathrm{w} / \mathrm{v}$ Tris-borate-EDTA gels containing glycerol $5 \% \mathrm{v} / \mathrm{v}$ and detected by silver staining [16]. The banding patterns on the gels were directly scanned to obtain migration distances and fragment sizes were calculated by the commercial software Gel Manager (BioSystematica, Tavistock, Devon). Fragments in the 615-1230-bp range were considered for the interpretation of PCR amplification patterns. Nonidentical patterns were identified as unique PCRribotypes (PCR-RTs).

Reproducibility and stability of the patterns obtained had been previously assessed on representative isolates of Enteritidis by multiple PCR amplifications of the same lysate and multiple DNA preparations and PCR amplifications on repeated subcultures of the same isolate [10].

\section{Results}

The results obtained by phage typing and PCR ribotyping are summarised in Table 1 . The characteristics of Enteritidis strains isolated from 36 of the 58 foodborne outbreaks studied are illustrated in Table 2. In 11 of the remaining 22 outbreaks, only one isolate was available from food or human cases and, in the remainder, two human isolates with identical phage types and PCR ribotypes were obtained.

\section{Phage typing}

Seven PTs were detected among the 243 isolates studied. Eight isolates were RDNC. Three foodpoisoning outbreaks which occurred in the years 1980 and 1986 were associated with PT8, 37 which occurred since 1982 were caused by PT4, seven outbreaks which occurred in the years 1993 and 1994 were associated with PT1 and three with RDNC strains. In eight cases - outbreaks nos. $6,8,11,13,14,15,19$ and 30 different PTs were recognised within strains isolated from the same outbreak.

\section{$P C R$ ribotyping}

Nine PCR-RTs were identified among the outbreakrelated strains (Figs. 1 and 2). PCR-RTs al and $\mathrm{d} 4$ were identified in the strains isolated from three 
Table 1. Results of phage typing and PCR ribotyping of 243 epidemic strains of $S$. enterica serotype Enteritidis isolated in Italy in the years 1980-1994

\begin{tabular}{|c|c|c|c|c|}
\hline $\begin{array}{l}\text { Year of } \\
\text { isolation }\end{array}$ & Phage type & $\begin{array}{l}\text { Number of } \\
\text { isolates }\end{array}$ & PCR ribotype & $\begin{array}{l}\text { Number of } \\
\text { isolates }\end{array}$ \\
\hline 1980 & 8 & 4 & al & 4 \\
\hline 1982 & 4 & 6 & e5 & 6 \\
\hline \multirow[t]{2}{*}{1986} & 4 & 5 & i10 & 5 \\
\hline & 8 & 1 & $\mathrm{~d} 4$ & 1 \\
\hline \multirow[t]{2}{*}{1989} & 4 & 17 & $\mathrm{f} 7$ & 15 \\
\hline & & & e5 & 2 \\
\hline \multirow[t]{2}{*}{1990} & 4 & 4 & f7 & 4 \\
\hline & 1 & 1 & f7 & 1 \\
\hline \multirow[t]{8}{*}{1991} & 4 & 33 & $\mathrm{f} 7$ & 18 \\
\hline & & & e5 & 9 \\
\hline & & & $\mathrm{b} 2$ & 2 \\
\hline & & & $\mathrm{d} 4$ & 2 \\
\hline & & & h9 & 2 \\
\hline & RDNC & 2 & f7 & 2 \\
\hline & 4/6/RDNC ${ }^{*}$ & 1 & f7 & 1 \\
\hline & $5 a$ & 1 & $f 7$ & 1 \\
\hline \multirow[t]{10}{*}{1992} & 4 & 31 & e5 & 12 \\
\hline & & & b2 & 10 \\
\hline & & & $\mathrm{f} 7$ & 9 \\
\hline & 1 & 5 & $\mathrm{f} 7$ & 5 \\
\hline & RDNC & 4 & t19 & 2 \\
\hline & & & e5 & 1 \\
\hline & & & f7 & 1 \\
\hline & $5 a$ & 2 & e5 & 2 \\
\hline & 7 & 1 & e5 & 1 \\
\hline & 30 & 1 & $\mathrm{f} 7$ & 1 \\
\hline \multirow[t]{5}{*}{1993} & 4 & 31 & e5 & 13 \\
\hline & & & $\mathrm{b} 2$ & 12 \\
\hline & & & $\mathrm{u} 20$ & 5 \\
\hline & & & h9 & 1 \\
\hline & 1 & 18 & $\mathrm{f} 7$ & 18 \\
\hline \multirow[t]{5}{*}{1994} & 4 & 56 & e5 & 41 \\
\hline & & & f7 & 15 \\
\hline & 1 & 17 & f7 & 10 \\
\hline & & & e5 & 7 \\
\hline & RDNC & 2 & $f 7$ & 2 \\
\hline
\end{tabular}

${ }^{*}$ PTs 4,6 , RDNC or mixed lytic patterns were detected.

foodborne outbreaks that occurred in the years 1980 and 1986, and PCR-RTs i10, t19, u20 and h9 were isolated from four outbreaks occurring in 1986, 1992 and 1993, respectively. Five, 21 and 23 outbreaks were caused by strains of Enteritidis belonging to PCR-RTs b2, e5 and f7, respectively. In two cases (outbreaks 10 and 11) more than one PCR-RT was identified among isolates from a single epidemic event.

\section{Correlation between PT and PCR-RT}

The three outbreak-related groups of strains of PT8 could be subdivided into two PCR-RT al and one PCRRT d4, respectively.

The RDNC strains showed PCR-RT $\mathrm{f} 7$ in two cases and PCR-RT t19 in one case.

Among seven sets of isolates belonging to PT1, six were attributed to PCR-RT f7 and one to PCR-RT e5. This observation is consistent with the findings of previous work on isolates of Enteritidis from Southern Italy that showed a close relatedness between epidemic PT1 strains and PCR-RT $\mathrm{f} 7$ and, at the same time, nine of 18 sporadic PT1 strains were identified as PCR-RT $\mathrm{f7}$; the remaining nine consisted of four distinct PCR profiles, b2, d4, e5 and $\mathrm{m} 12$ [10].

Of the 37 PT4 foodborne outbreaks, 36 were subdivided by PCR ribotyping into six subsets: 17 were attributed to PCR-RT e5, 11 to PCR-RT f7, five to PCR-RT b2, and one each to PCR-RT i10, PCR-RT u20 and PCR-RT h9. Data from epidemiological investigations were consistent in almost all cases with clustering of strains as shown by PCR-ribotyping.

In one outbreak (no. 10) two different PCR-RTs were recognised: e5 was detected in one isolate from chicken eggs and d4 in Enteritidis strains from ice cream and human stool. Interestingly, the egg isolate shared the same PCR-RT e5 as that from chicken eggs involved in outbreak no. 9 which occurred at the same time in Reggio Emilia, Northern Italy. Epidemiological investigation had demonstrated that eggs implicated in the two outbreaks had been acquired from the same laying flock.

Outbreak no. 11 involved elderly patients and staff members of a nursing home (Table 2, i), homeassisted patients (ii) and guests of a hotel (iii). Epidemiological investigation had indicated egg-containing dishes provided by a common catering service as the presumed vehicle of infection, but phage typing identified three different types, so failing to confirm the attribution of the three events to a single bacterial clone. PCR ribotyping also yielded three different profiles, but isolates from the nursing home and from home-assisted persons were all attributed to the same clone of PCR-RT f7, although one was identified as PCR-RT e5, whilst strains from hotel guests shared a quite distinct PCR-RT h9. All the strains possessed the 38-MDa serotype-specific plasmid alone, except for the PCR-RT e5 isolate, which exhibited an additional plasmid of $67.7 \mathrm{MDa}$ (data not shown).

\section{Discussion}

Various techniques have been used to subdivide Enteritidis strains within the predominant phage types. These include plasmid profiling $[17,18]$, IS200 typing [19], pulsed-field gel electrophoresis [20,21] and ribotyping [18, 20-22]. Nevertheless, application of these techniques to strains belonging to PT4 or PT8, which have caused the majority of the outbreaks reported in Europe and in the United States, respectively, exhibited insufficient discriminatory power in many instances and consequently often proved to be unsuitable as effective epidemiological tools. On the other hand, these observations have been interpreted as support for the hypothesis of the clonal dissemination of pathogenic strains of Enteritidis.

PCR ribotyping was used in previous work on 
Table 2. Characteristics of strains of $S$. enterica serotype Enteritidis isolated from 36 foodborne outbreaks occurring in Italy in the years 1980-1994

\begin{tabular}{|c|c|c|c|c|c|c|c|}
\hline $\begin{array}{l}\text { Outbreak } \\
\text { no. }\end{array}$ & $\begin{array}{l}\text { Year of } \\
\text { isolation }\end{array}$ & $\begin{array}{l}\text { Geographic } \\
\text { origin }\end{array}$ & $\begin{array}{l}\text { Epidemio- } \\
\text { logical } \\
\text { context }\end{array}$ & $\begin{array}{l}\text { Number of } \\
\text { typed strains }\end{array}$ & $\begin{array}{l}\text { Phage } \\
\text { type }\end{array}$ & $\begin{array}{l}\text { PCR } \\
\text { ribotype }\end{array}$ & Source \\
\hline 1 & 1982 & Agrigento, Southern Italy & $\mathrm{f}$ & 6 & 4 & e5 & Human stool \\
\hline 2 & 1986 & Caserta, Southern Italy & $f$ & 5 & 4 & $\mathrm{i} 10$ & Human stool \\
\hline \multirow[t]{4}{*}{3} & 1989 & Verona, Northern Italy (i) $\dagger$ & $\mathrm{r}$ & 2 & 4 & f7 & Human stool \\
\hline & & (ii) $\dagger$ & & 1 & 4 & $\mathrm{f} 7$ & Human stool \\
\hline & & (iii) $\dagger$ & & 3 & 4 & f7 & $\begin{array}{l}\text { Egg-based unspecified } \\
\text { food }\end{array}$ \\
\hline & & & & 2 & 4 & f7 & Human stool \\
\hline \multirow[t]{2}{*}{4} & 1989 & Teramo, Central Italy & f & 2 & 4 & $\mathrm{f} 7$ & Cream pie \\
\hline & & & & 1 & 4 & $\mathrm{f} 7$ & Human stool \\
\hline \multirow[t]{2}{*}{5} & 1989 & Teramo, Central Italy & $r$ & 1 & 4 & $\mathrm{f} 7$ & Lasagna \\
\hline & & & & 2 & 4 & $\mathrm{f} 7$ & Human stool \\
\hline \multirow[t]{3}{*}{6} & 1990 & Massa Carrara, Central Italy & $\mathrm{f}$ & 1 & 4 & $\mathrm{f} 7$ & Unknown food \\
\hline & & & & 3 & 4 & f7 & Human stool \\
\hline & & & & 1 & 1 & f7 & Human stool \\
\hline \multirow[t]{2}{*}{7} & 1991 & Cremona, Northern Italy & $\mathrm{f}$ & 1 & 4 & f7 & Home-made ice cream \\
\hline & & & & 3 & 4 & f7 & Human stool \\
\hline \multirow[t]{2}{*}{8} & 1991 & Reggio Emilia, Northern & $\mathrm{r}$ & 1 & $5 a$ & f7 & Omelette \\
\hline & & Italy & & 2 & 4 & f7 & Human stool \\
\hline 9 & 1991 & $\begin{array}{l}\text { Reggio Emilia, Northern } \\
\text { Italy }\end{array}$ & $\mathrm{r}$ & 1 & 4 & e5 & Chicken egg \\
\hline \multirow[t]{3}{*}{10} & 1991 & Reggio Emilia, Northern & $\mathrm{r}$ & 1 & 4 & e5 & Chicken egg \\
\hline & & Italy & & 1 & 4 & $\mathrm{~d} 4$ & Home-made ice cream \\
\hline & & & & 1 & 4 & d4 & Human stool \\
\hline \multirow[t]{6}{*}{11} & 1991 & Fidenza, Northern Italy (i) $\ddagger$ & $\mathrm{r}$ & 1 & 4/6/RDNC§ & f7 & Human stool \\
\hline & & & & 1 & RDNC & f7 & Human stool \\
\hline & & & & 8 & 4 & f7 & Human stool \\
\hline & & (ii) $\$$ & & 1 & RDNC & $\mathrm{f} 7$ & Human stool \\
\hline & & & & 1 & 4 & e5 & Human stool \\
\hline & & $($ iii $) \ddagger$ & & 2 & 4 & h9 & Human stool \\
\hline \multirow[t]{2}{*}{12} & 1991 & Palermo, Southern Italy & $\mathrm{f}$ & 1 & 4 & e5 & Tiramisu \\
\hline & & & & 3 & 4 & e5 & Human stool \\
\hline \multirow[t]{2}{*}{13} & 1992 & Aosta, Northern Italy & $\mathrm{h}$ & 1 & 30 & f7 & Human stool \\
\hline & & & & 5 & 1 & f7 & Human stool \\
\hline \multirow[t]{3}{*}{14} & 1992 & Frosinone, Central Italy & $\mathrm{f}$ & 1 & 7 & e5 & Human stool \\
\hline & & & & 1 & 4 & e5 & $\begin{array}{l}\text { Egg-based unspecified } \\
\text { food }\end{array}$ \\
\hline & & & & 2 & 4 & e5 & Human stool \\
\hline \multirow[t]{2}{*}{15} & 1992 & Teramo, Central Italy & $\mathrm{r}$ & 1 & RDNC & e5 & Artichoke \\
\hline & & & & 1 & 4 & e5 & Lamb meat \\
\hline 16 & 1992 & Teramo, Central Italy & $\mathrm{f}$ & 1 & 4 & e5 & Tiramisu \\
\hline & & & & 1 & 4 & e5 & Human stool \\
\hline 17 & 1992 & Genoa, Northern Italy & $f$ & 4 & 4 & $\mathrm{~b} 2$ & $\begin{array}{l}\text { Egg-based unspecified } \\
\text { food }\end{array}$ \\
\hline & & & & 4 & 4 & b2 & Human stool \\
\hline 18 & 1992 & Genoa, Northern Italy & $\mathrm{f}$ & 1 & RDNC & t19 & Tiramisu \\
\hline & & & & 1 & RDNC & t19 & Human stool \\
\hline 19 & 1992 & Modena, Northern Italy & $\mathrm{h}$ & 1 & 4 & e5 & Tiramisu \\
\hline & & & & 2 & $5 a$ & e5 & Chicken egg \\
\hline & & & & 2 & 4 & e5 & Human stool \\
\hline 20 & 1992 & Modena, Northern Italy & $\mathrm{r}$ & 4 & 4 & f7 & Tiramisu \\
\hline 21 & 1992 & Rome, Central Italy & $\mathrm{r}$ & 1 & 4 & $\mathrm{f} 7$ & Sandwiches \\
\hline & & & & 3 & 4 & f7 & Human stool \\
\hline 22 & 1993 & Bergamo, Northern Italy & $r$ & 5 & 1 & f7 & Human stool \\
\hline 23 & 1993 & Verona, Northern Italy & $\mathrm{f}$ & 1 & 1 & f7 & Home-made mayonnaise \\
\hline & & & & 2 & 1 & $\mathrm{f} 7$ & Human stool \\
\hline 24 & 1993 & Colorno, Northern Italy & $\mathrm{f}$ & 5 & 4 & $\mathrm{u} 20$ & Human stool \\
\hline 25 & 1993 & Palermo, Southern Italy & $\mathrm{f}$ & 1 & 1 & $\mathrm{f} 7$ & Home-made mayonnaise \\
\hline & & & & 1 & 1 & f7 & Human stool \\
\hline 26 & 1993 & Cosenza, Southern Italy & $\mathrm{f}$ & 1 & 4 & $\mathrm{~b} 2$ & Egg-based unspecified \\
\hline & & & & 10 & 4 & $\mathrm{~b} 2$ & $\begin{array}{l}\text { food } \\
\text { Human stool }\end{array}$ \\
\hline 27 & 1993 & Cosenza, Southern Italy & $\mathrm{f}$ & 1 & 4 & e5 & Egg-based unspecified \\
\hline & & & & 11 & 4 & e5 & $\begin{array}{l}\text { food } \\
\text { Human stool }\end{array}$ \\
\hline 28 & 1993 & Messina, Southern Italy & $\mathrm{r}$ & 3 & 1 & f7 & Tartines \\
\hline & & & & 3 & 1 & f7 & Human stool \\
\hline 29 & 1994 & $\begin{array}{l}\text { Lentate sul Seveso, Northern } \\
\text { Italy }\end{array}$ & $\mathrm{r}$ & 5 & 4 & e5 & $\begin{array}{l}\text { Vitello tonnato - home- } \\
\text { made mayonnaise }\end{array}$ \\
\hline & & & & 26 & 4 & e5 & Human stool \\
\hline 30 & 1994 & Modena, Northern Italy & $\mathrm{r}$ & 2 & 1 & f7 & Ice cream \\
\hline & & & & 5 & 1 & $\mathrm{f} 7$ & Human stool \\
\hline & & & & 2 & 4 & f7 & Human stool \\
\hline
\end{tabular}


Table 2. continued

\begin{tabular}{|c|c|c|c|c|c|c|c|}
\hline $\begin{array}{l}\text { Outbreak } \\
\text { no. }\end{array}$ & $\begin{array}{l}\text { Year of } \\
\text { isolation }\end{array}$ & $\begin{array}{l}\text { Geographic } \\
\text { origin }\end{array}$ & $\begin{array}{c}\text { Epidemio- } \\
\text { logical } \\
\text { context }^{*}\end{array}$ & $\begin{array}{l}\text { Number of } \\
\text { typed strains }\end{array}$ & $\begin{array}{l}\text { Phage } \\
\text { type }\end{array}$ & $\begin{array}{l}\text { PCR } \\
\text { ribotype }\end{array}$ & Source \\
\hline 31 & 1994 & Frosinone, Central Italy & $\mathrm{r}$ & 7 & 1 & e5 & Human stool \\
\hline 32 & 1994 & Livorno, Central Italy & $\mathrm{r}$ & 1 & 1 & f7 & Pastries \\
\hline 33 & 1994 & Milan, Northern Italy & f & $\begin{array}{l}2 \\
5\end{array}$ & $\begin{array}{l}1 \\
4\end{array}$ & $\begin{array}{l}\mathrm{f} 7 \\
\mathrm{e} 5\end{array}$ & $\begin{array}{l}\text { Human stool } \\
\text { Human stool }\end{array}$ \\
\hline 34 & 1994 & Teramo, Central Italy & $f$ & 1 & 4 & f7 & Sheep milk \\
\hline 35 & 1994 & Milan, Northern Italy & $\mathrm{f}$ & $\begin{array}{l}2 \\
1 \\
1\end{array}$ & $\begin{array}{l}4 \\
4 \\
4\end{array}$ & $\begin{array}{l}\text { f7 } \\
\text { e5 } \\
\text { e5 }\end{array}$ & $\begin{array}{l}\text { Human stool } \\
\text { Vitello tonnato } \\
\text { Human stool }\end{array}$ \\
\hline 36 & 1994 & Enna, Southern Italy & $\mathrm{r}$ & $\begin{array}{l}3 \\
7\end{array}$ & $\begin{array}{l}4 \\
4\end{array}$ & $\begin{array}{l}\text { f7 } \\
\text { f7 }\end{array}$ & $\begin{array}{l}\text { Ice cream } \\
\text { Human stool }\end{array}$ \\
\hline
\end{tabular}

*h, hospital; f, family; $r$, food processing and catering establishment.

†Consecutive outbreaks in the same restaurant.

$¥$ The three foodborne events were attributed to foodstuffs provided by a single catering kitchen.

$\S \mathrm{PTs} 4,6, \mathrm{RDNC}$ or mixed lytic patterns were detected.
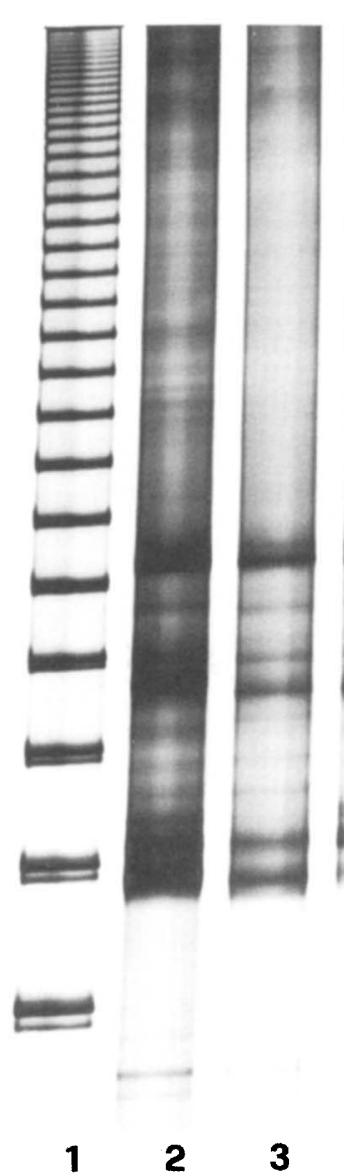
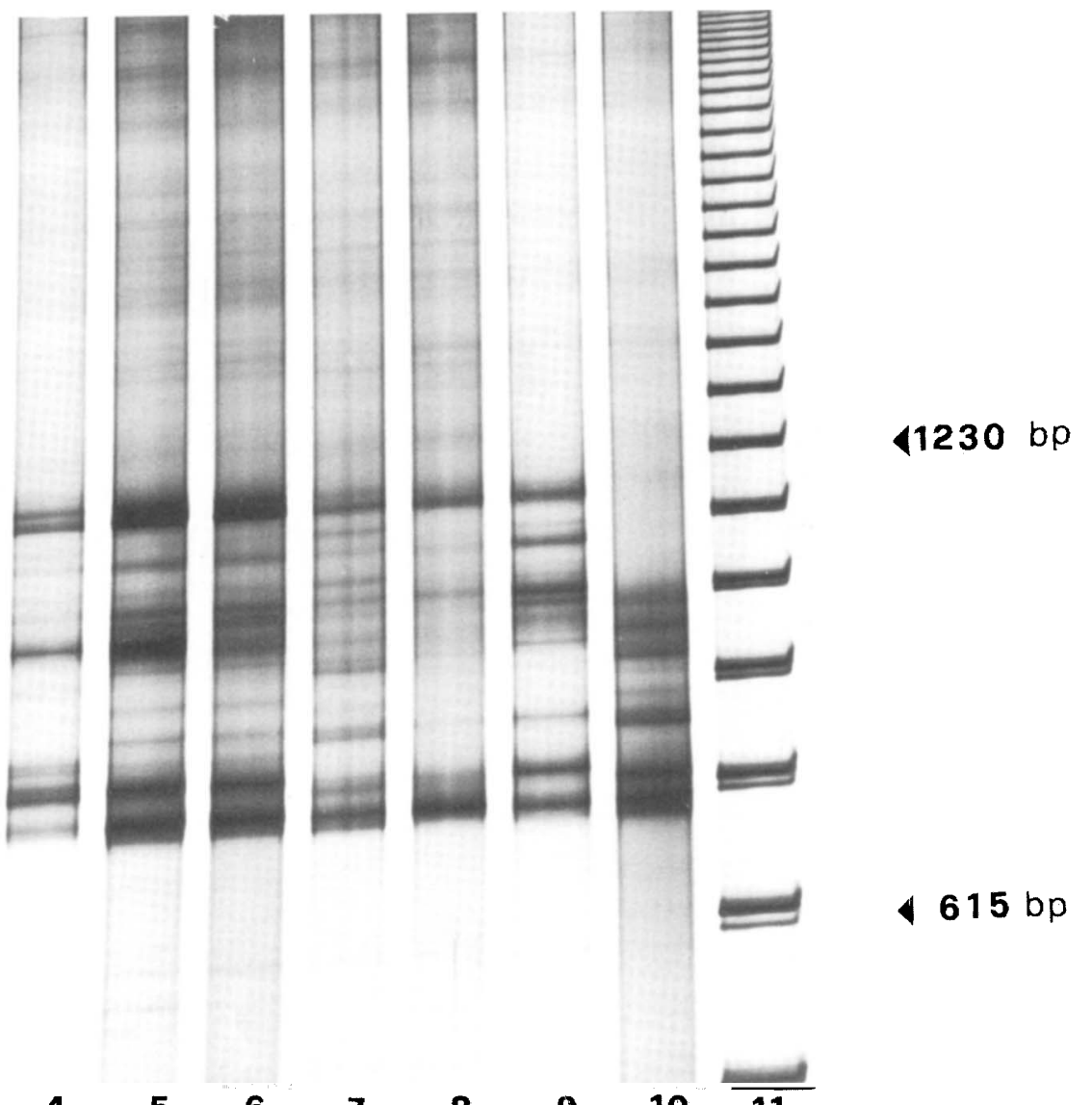

$11230 \mathrm{bp}$

$4615 \mathrm{bp}$
Human stool
Sheep milk
Human stool
Human stool
Ice cream

Fig. 1. Polymerase chain reaction ribotypes (PCR-RTs) identified among epidemic strains of S. enterica serotype Enteritdis isolated in the years 1980-1994. Lanes: 1 and 11, mol. wt marker 123-bp ladder (Gibco-BRL); 2, PCR-RT a1; 3, PCR-RT b2; 4, PCR-RT d4; 5, PCR-RT e5; 6, PCR-RT f7; 7, PCR-RT h9; 8, PCR-RT i10; 9, PCR-RT t19; 10, PCR-RT u20.

Enteritidis strains isolated in Southern Italy in the years 1980-1994 and was able to detect multiple clones within the most frequent phage types [10]. In the present study, analysis of PCR ribotypes of isolates from 58 foodborne outbreaks occurring in different regions of Italy in the same period further confirmed the usefulness of this molecular method to monitor the epidemic spread of Enteritidis. In particular, identification of distinct patterns among PT4 strains appeared to be effective in grouping epidemiologically linked strains and in characterising otherwise undistinguishable outbreak isolates. Moreover, seven of eight outbreaks from which different phage types had been identified proved to be related 


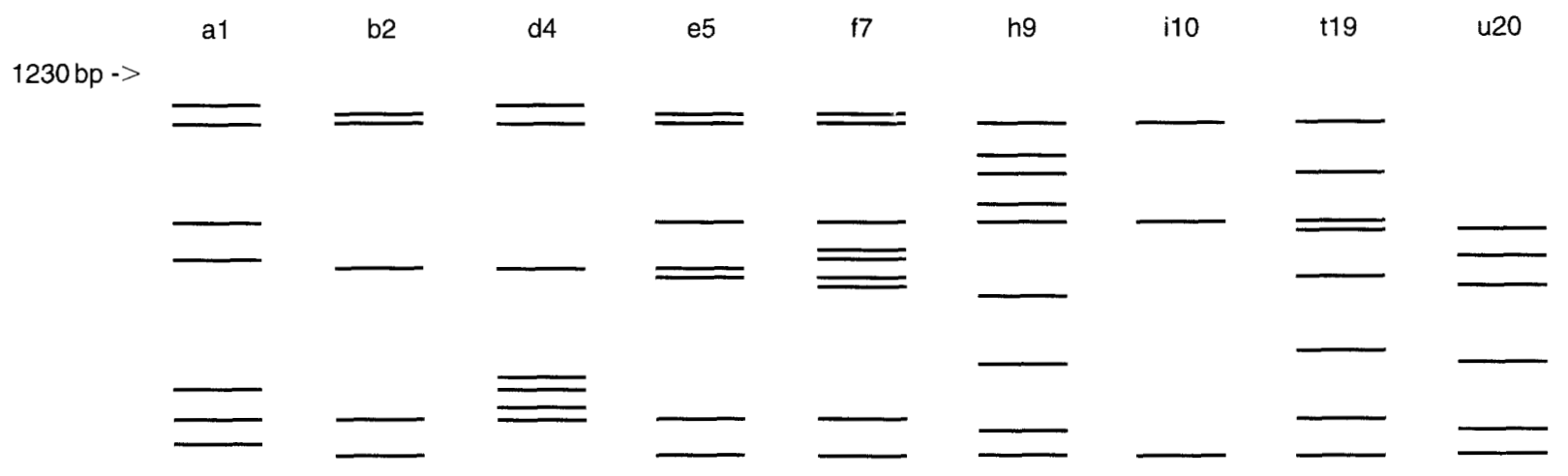

$615 \mathrm{bp}->$

Fig. 2. PCR-amplification patterns of S. enterica serotype Enteritidis. Lanes 1-11, as for Fig. 1.

to a single bacterial strain. Phage type heterogeneity observed in such instances presumably depends on phage conversion phenomena [9].

In our experience PCR ribotyping is a simple and reliable technique that allows the rapid generation of molecular fingerprints and is also suitable for largescale screening of bacterial isolates for epidemiological monitoring purposes. Nevertheless, the requirements in terms of availability of equipment and skill of personnel and lack of inter-laboratory standardisation suggest that PCR ribotyping should preferably be performed in specialised reference laboratories

This work was supported by a grant $(40 \%)$ of the Ministero dell'Università e della Ricerca Scientifica e Tecnologica.

\section{References}

1. Hedberg $\mathrm{CW}$, David MJ, White KE, MacDonald KL, Osterholm MT. Role of egg consumption in sporadic Salmonella enteritidis and Salmonella typhimurium infections in Minnesota. $J$ Infect Dis 1993; 167: 107-111.

2. Rodrigue DC, Tauxe RV, Rowe B. International increase in Salmonella enteritidis: a new pandemic? Epidemiol Infect 1990; 105: 21-27.

3. Hickman-Brenner FW, Stubbs AD, Farmer JJ. Phage typing of Salmonella enteritidis in the United States. J Clin Microbiol 1991; 29: 2817-2823.

4. Anonymous. PHLS-SVS: update on salmonella infection. Public Health Laboratory Service-State Veterinary Service 1993; 14.

5. Schroeter A, Ward LR, Rowe B, Protz D, Hartung M, Helmuth R. Salmonella enteritidis phage types in Germany. Eur $J$ Epidemiol 1994; 10: 645-648.

6. Binkin N, Scuderi G, Novaco F et al. Egg-related Salmonella enteritidis, Italy, 1991. Epidemiol Infect 1993; 110: 227-237.

7. Frost JA, Ward LR, Rowe B. Acqusition of a drug resistance plasmid converts Salmonella enteritidis phage type 4 to phage type 24. Epidemiol Infect 1989; 103: 243-248.

8. Chart H, Rowe B, Threlfall EJ, Ward LR. Conversion of Salmonella enteritidis phage type 4 to phage type 7 involves loss of lipopolysaccharide with concomitant loss of virulence. F EMS Microbiol Lett 1989; 60: 37-40.

9. Rankin S, Platt DJ. Phage conversion in Salmonella enterica serotype Enteritidis: implications for epidemiology. Epidemiol Infect 1995, 114: 227-236.

10. Nastasi A, Mammina C. Epidemiology of Salmonella enterica serotype Enteritidis infections in southern Italy during the years 1980-1994. Res Microbiol 1996; 147: 393-403.

11. Dasen SE, LiPuma JJ, Kostman JR, Stull TL. Characterization of PCR-ribotyping for Burkholderia (Pseudomonas) cepacia. $J$ Clin Microbiol 1994; 32: 2422-2424.

12. Kostman JR, Edlind TD, LiPuma JJ, Stull TL. Molecular epidemiology of Pseudomonas cepacia determined by polymerase chain reaction ribotyping. J Clin Microbiol 1992; 30: 2084-2087.

13. Kostman JR, Alden MB, Mair M, Edlind TD, LiPuma JJ, Stull TL. A universal approach to bacterial molecular epidemiology by polymerase chain reaction ribotyping. J Infect Dis 1995; 171: 204-208.

14. Edwards PR, Ewing WH. Edwards and Ewing's Identification of Enterobacteriaceae, 4th edn. New York, Elsevier Science. 1986.

15. Ward LR, deSa JDH, Rowe B. A phage-typing scheme for Salmonella enteritidis. Epidemiol Infect 1987; 99: 291-294.

16. Herring AJ, Inglis NF, Ojeh CK, Snodgrass DR, Menzies JD. Rapid diagnosis of rotavirus infection by direct detection of viral nucleic acid in silver-stained polyacrylamide gels. $J$ Clin Microbiol 1982; 16: 473-477.

17. Threlfall EJ, Rowe B, Ward LR. Subdivision of Salmonella enteritidis phage types by plasmid profile typing. Epidemiol Infect 1989; 102: 459-465.

18. Martinetti G, Altwegg M. rRNA gene restriction patterns and plasmid analysis as a tool for typing Salmonella enteritidis. Res Microbiol 1990; 141: 1151-1162.

19. Stanley J, Burnens AP, Threlfall EJ, Chowdry N, Goldsworthy M. Genetic relationships among strains of Salmonella enteritidis in a national epidemic in Switzerland. Epidemiol Infect 1992; 108: 213-220.

20. Powell NG, Threlfall EJ, Chart H, Schofield SL, Rowe B. Correlation of change in phage type with pulsed field profile and $16 \mathrm{rrn}$ profile in Salmonella enteritidis phage types 4, 7 and 9a. Epidemiol Infect 1995; 114: 403-411.

21. Thong K-L, Ngeow Y-F, Altwegg M, Navaratnam P, Pang T. Molecular analysis of Salmonella enteritidis by pulsed-field gel electrophoresis and ribotyping. $J$ Clin Microbiol 1995; 33: 10-70-1074.

22. Usera MA, Popovic T, Bopp CA, Strockbine NA. Molecular subtyping of Salmonella enteritidis phage type 8 strains from the United States. J Clin Microbiol 1994; 32: 194-198. 